RESEARCH ARTICLE

Hazar Harbalioglu ${ }^{1}$

Omer Genc ${ }^{2}$

Gokhan Alici ${ }^{3}$

Alaa Quisi ${ }^{4}$

Abdullah Yildirim ${ }^{3}$

${ }^{1}$ Duzce State Hospital, Department of Cardiology, Duzce, Turkey

${ }^{2}$ Agri Training and Research Hospital, Department of Cardiology, Agri, Turkey

${ }^{3}$ Adana City Training and Research Hospital, Department of Cardiology, Adana, Turkey

${ }^{4}$ Medline Adana Hospital, Department of Cardiology. Adana, Turkey

Corresponding Author: Hazar Harbalioglu Duzce State Hospital, Department of Cardiology, Duzce, Turkey mail: hazarhmail@hotmail.com Phone: +90 5363602980

Received: 20.04.2021

Acceptance: 03.07.2021

DOI: $10.18521 / \mathrm{ktd} .922646$

Konuralp Medical Journal e-ISSN1309-3878

konuralptipdergi@duzce.edu.tr konuralptipdergisi@gmail.com www.konuralptipdergi.duzce.edu.tr

\section{Features on ECG During Admission May Predict In-hospital Events for COVID-19 Patients ABSTRACT}

Objective: To evaluate the association of electrocardiography (ECG) features obtained on admission with treating units and in-hospital all-cause mortality in coronavirus disease (COVID-19) patients.

Methods: A total of 172 hospitalized COVID-19 patients who were diagnosed by detecting severe acute respiratory syndrome coronavirus-2 (SARS-CoV-2) with real-time reversetranscription polymerase chain reaction method between 15 May and 17 June 2020 were consecutively enrolled in the study. Laboratory parameters and findings on ECG obtained during admission were recorded. Criteria for hospitalization and intensive care unit (ICU) admission were determined in accordance with the interim guidance of the Republic of Turkey Ministry of Health. Patients were divided according to their in-hospital mortality status and units where patients were treated.

Results: The median age was significantly higher in the non-survivors group and in patients treated in the ICU ( $\mathrm{p}<0.05$, for both). PR duration, P dispersion, QRS duration $\left(\mathrm{QRS}_{\mathrm{d}}\right)$, corrected $\mathrm{QT}$ duration $\left(\mathrm{QT}_{\mathrm{c}}\right)$, and $\mathrm{QT}$ dispersion $\left(\mathrm{QT}_{\mathrm{d}}\right)$ were significantly longer in patients treated in the ICU ( $<<0.001$, for all), whilst PR duration, $\mathrm{P}$ dispersion, $\mathrm{QRS}_{\mathrm{d}}, \mathrm{QT}_{\mathrm{d}}$, and $\mathrm{QT}_{\mathrm{c}}$ were significantly longer in the non-survivors group ( $\mathrm{p}<0.05$, for all). $\mathrm{QT}_{\mathrm{d}}$ predicted admission to ICU, whereas $\mathrm{QRS}_{\mathrm{d}}$ predicted in-hospital all-cause mortality in patients with COVID-19.

Conclusions: Findings on ECG during admission may be independently associated with treating units and in-hospital all-cause mortality in COVID-19 patients.

Keywords: ECG, QRS Duration, QT Dispersion, COVID-19, ICU Admission.

\section{COVID-19 Hastalarında Başvuru Esnasında EKG'deki Özellikler Hastane İçi Olayları Öngörebilir \\ ÖZET}

Amaç: COVID-19 hastalarında başvuru esnasındaki elektrokardiyografi (EKG) özellikleri ile tüm nedenlere bağlı hastane-içi mortalite ile tedavi üniteleri arasındaki ilişkiyi değerlendirmektir.

Gereç ve Yöntem: 15 Mart ile 17 Haziran 2020 tarihleri arasında gerçek zamanlı ters transkripsiyon polimeraz zincir reaksiyonu metodu ile şiddetli akut solunum sendromu koronavirüs-2 (SARS-CoV-2) tespit edilerek COVID-19 tanısı konulan ve hastaneye yatırılan toplam 172 ardışı hasta bu çalışmaya dahil edildi. Laboratuvar parametreleri ve EKG bulguları başvuru sırasında kaydedildi. Hastaneye ve yoğun bakım ünitesine (YBÜ) yatış kriterleri Türkiye Cumhuriyeti Sağlık Bakanlığı' nın geçici kılavuzuna göre belirlendi. Hastalar hastane içi mortalite durumlarına ve tedavi gördükleri birime göre gruplandırıldı. Bulgular: Ortanca yaş mortalite grubunda ve YBÜ' de tedavi edilen hastalarda önemli ölçüde daha yüksekti (her ikisi için, $\mathrm{p}<0.05$ ). P dispersiyonu, QRS süresi, düzeltilmiş $\mathrm{QT}$ süresi $\left(\mathrm{QT}_{\mathrm{c}}\right)$ ve $\mathrm{QT}$ dispersiyonu $\left(\mathrm{QT}_{\mathrm{d}}\right)$ YBÜ' de tedavi edilen hastalarda önemli ölçüde daha uzundu (hepsi için, $\mathrm{p}<0.001$ ). $\mathrm{PR}$ süresi, $\mathrm{P}$ dispersiyonu, $\mathrm{QRS}$ süresi, $\mathrm{QT}_{\mathrm{d}} \mathrm{ve}_{\mathrm{Q}} \mathrm{QT}_{\mathrm{c}}$ süresi mortalite grubunda önemli ölçüde daha uzundu (hepsi için, $\mathrm{p}<0.05$ ). $\mathrm{QT}_{\mathrm{d}} \mathrm{YBÜ}$ başvurularını öngörürken QRS süresi COVID-19 hastalarında tüm nedenlere bağlı hastaneiçi mortaliteyi öngördü.

Sonuç: Başvuru esnasındaki EKG bulguları, COVID-19 hastalarında tedavi birimleri ve tüm nedenlere bağlı hastane-içi mortalite ile bağımsız olarak ilişkilendirilebilir.

Anahtar Kelimeler: EKG, QRS Süresi, QT Dispersiyonu, COVID-19, YBÜ Başvurusu. 


\section{INTRODUCTION}

Coronavirus disease (COVID-19) is an infectious disease caused by severe acute respiratory coronavirus-2 (SARS-CoV-2). Most hospitalized individuals are over 65-year-old, male, and those with multi-comorbidities (1). Patients could have a variety of clinical courses ranging from an asymptomatic stage to pneumonia, acute respiratory distress syndrome, and multi-organ failure (2-5). SARS-CoV-2 enters the cell by binding to angiotensin-converting enzyme-2 which is found in many organs, especially lungs, cardiovascular system, kidneys, gastrointestinal system, and testicles (6), and may lead to myocarditis, arrhythmias, and cardiac death (7-9). Thus, COVID-19 appears to be a multi-systemic infectious disease. Hospitalized patients with COVID-19 are treated in emergency rooms, inpatient rooms, and intensive care units (ICU). Additionally, in-hospital mortality rates may vary depending on the unit where patients are treated (10).

Electrocardiography (ECG), a simple and easily accessible tool, is utilized to define arrhythmias, abnormal findings in acute and chronic heart diseases, ST-T changes as well as electrical conduction disorders (11). Changes in QRS duration $\left(\mathrm{QRS}_{\mathrm{d}}\right)$ that indicates ventricular depolarization or QT dispersion $\left(\mathrm{QT}_{\mathrm{d}}\right)$ associated with ventricular repolarization could give rise to ventricular arrhythmias and thus cardiac deaths (1216). No consensus in the literature exists regarding the relationship between ECG findings and poor outcomes in infectious diseases. Therefore, the purpose of the present study is to examine the association of ECG features on admission with treating units and in-hospital all- cause mortality in COVID-19 patients.

\section{MATERIAL AND METHODS}

Study Population and Design: This is a single-center (Adana City Training and Research Hospital) and retrospective observational cohort study that includes a total of 172 consecutively hospitalized COVID-19 patients diagnosed by detecting SARS-CoV-2 RNA with real-time reverse-transcription polymerase chain reaction method from 15 May to 17 June 2020. Subjects were grouped according to their in-hospital mortality status, as survivors $(n=155)$ and nonsurvivors $(\mathrm{n}=17)$, and units where patients are treated, as ICU $(n=23)$ and inpatient room $(n=149)$. ECG parameters of the study population were obtained only based on ECG taken during admission. Age, gender, and comorbidities were achieved from their anamnesis during hospitalization or from the medical record system. Laboratory parameters including complete blood cell count, white blood cell count, urea, creatinine, glomerular filtration rate (GFR), alanine transaminase (ALT), aspartate transaminase (AST), and lactate dehydrogenase (LDH) were analyzed from the blood samples taken on admission. The neutrophil-lymphocyte ratio (NLR) was calculated by dividing the absolute neutrophil count by the absolute lymphocyte count from a complete blood count. GFR was calculated with the Modification of Diet in Renal Disease formula (17). The study was conducted according to the Declaration of Helsinki and was approved by an institutional ethics committee (No: 99, May 15, 2020), as well as the Ministry of Health. The need for written informed consent was waived due to the retrospective nature of the study.

Hospitalization was planned according to the following criteria determined by the Republic of Turkey Ministry of Health (18);

- Confusion or tachycardia (>125 bpm)

- Dyspnea or tachypnea ( $>22$ breaths/min)

- Hypotension $(<90 / 60 \mathrm{mmHg}$ or mean blood pressure $<65 \mathrm{mmHg}$ )

- $>50$ year-old and presence of co-morbidity (immunosuppressive conditions, especially cardiovascular diseases, diabetes mellitus, hypertension, cancer, chronic lung diseases)

- Mild-moderate pneumonia and blood lymphocyte count $<800 / \mu 1$ or serum CRP $>40$ $\mathrm{mg} / \mathrm{l}$ or ferritin $>500 \mathrm{ng} / \mathrm{ml}$ or D-dimer $>1000$ $\mathrm{ng} / \mathrm{ml}$, etc.

- Presence of bilateral diffuse $(>50 \%)$ involvement in lung imaging

Criteria for ICU admission are described as follows; a) Dyspnea and respiratory distress despite oxygen therapy; respiratory rate $>30 / \mathrm{min}$ or $\mathrm{PaO} 2 / \mathrm{FiO} 2<300 \mathrm{mmHg}$ or $\mathrm{SpO} 2<90$ or $\mathrm{PaO} 2<70$ $\mathrm{mmHg}$, b) Hypotension (systolic blood pressure $<90 \mathrm{mmHg}$ and a decrease of systolic blood pressure higher than $40 \mathrm{mmHg}$ or mean arterial pressure $<65 \mathrm{mmHg}$, c) Acute kidney injury, acute liver dysfunction, development of acute organ dysfunction such as confusion, acute bleeding diathesis, and immunosuppression, d) Elevated troponin and arrhythmia, e) Lactate $>2 \mathrm{mmol} / \mathrm{L}, \mathrm{f}$ ) Presence of skin findings such as prolonged capillary filling time and cutis marmorata (18). Patients with chronic kidney disease (GFR <30 $\mathrm{ml} / \mathrm{min} / 1.73 \mathrm{~m}^{2}$ ), chronic liver failure, atrial fibrillation, immunosuppression, those using heart rate-reducing agents, or those under 16 years of age were excluded from the study.

ECG Analysis and Definitions: 12-lead ECG data taken on admission were recorded. 300\% magnification was applied to all ECGs obtained from individuals using Adobe Photoshop Software. ECG recordings (filter range $0.05-150 \mathrm{~Hz}, \mathrm{AC}$ filter $60 \mathrm{~Hz}, 25 \mathrm{~mm} / \mathrm{s}, 10 \mathrm{~mm} / \mathrm{mV}$, CardioFax S; Nihon Kohden, Tokyo, Japan) were manually analyzed by two independent cardiologists who were blinded to the present study for the following parameters: Heart rate, P-wave dispersion, PR duration, $\mathrm{QRS}_{\mathrm{d}}$, fragmented QRS complex, QT duration corrected by the Bazzett-formula $\left(\mathrm{QT}_{\mathrm{c}}\right)$ 
(19), $\mathrm{QT}_{\mathrm{d}}$, premature atrial contraction, premature ventricular contraction, ST depression, and T inversion. $\mathrm{QT}_{\mathrm{d}}$ was identified as the difference between the longest (QT $\mathrm{Tax}_{\max }$ ) and the shortest $\left(\mathrm{QT}_{\min }\right)$ QT intervals within a 12-lead ECG (20). Similarly, P-wave dispersion was described as the difference between the longest and the shortest $\mathrm{P}$ wave duration recorded from 12-lead surface ECG (21).

Statistical Analysis: An analytical (Kolmogorov-Smirnov test) method and visual methods (histograms and probability plots) were used to test the normality of distribution. Continuous variables were expressed as mean \pm standard deviation (SD) or median (interquartile range) and categorical variables were expressed as numbers and percentages (\%). The Student t-test and the Mann-Whitney U test were used to compare continuous variables. The Chisquare and Fisher's exact test were used to compare categorical variables as appropriate. All of the significant parameters in the univariate analysis with $p<0.1$ were selected for the multivariable model and backward stepwise logistic regression analysis was used to determine the independent predictors of
ICU admission and all-cause in-hospital mortality of COVID-19 patients. The odds ratio (OR) and 95\% confidence interval (CI) of each independent variable were calculated. Receiver operating characteristic (ROC) curve analysis was used to determine the cut-off value of independent predictors in predicting ICU admission based on the Youden index. A 2-tailed $p$-value of $<0.05$ was considered significant. In all statistical analyses; SPSS 20.0 Statistical Package Program for Windows (SPSS Inc., Chicago, IL, USA) and MedCalc statistical software v19.5.6 (Ostend, Belgium) were utilized.

\section{RESULTS}

There was no significant difference across the two groups by the treating units in terms of gender and comorbidities including hypertension, diabetes mellitus, hyperlipidemia, coronary artery disease, chronic obstructive pulmonary disease, heart failure, and current smoker. The median age of the patients treated in ICU was older than that in the patients treated in the inpatient room [68 (62-77) vs 44 (31-57), p<0,001]. Detailed demographic characteristics and laboratory parameters of the study population according to the treating units are shown in Table 1.

Table 1. Demographic and laboratory findings of the study population by the treating unit

\begin{tabular}{|c|c|c|c|c|}
\hline & Inpatient room (n:149) & ICU (n:23) & Overall (n:172) & $p$-value \\
\hline Age, years & $44(31-57)$ & $68(62-77)$ & $48(34-62)$ & $<0.001$ \\
\hline Sex, male, n (\%) & $71(47.6)$ & $13(56.5)$ & $84(48.8)$ & 0.428 \\
\hline Hypertension, n (\%) & $93(62.4)$ & $18(78.2)$ & $111(64.5)$ & 0.139 \\
\hline Diabetes mellitus, n (\%) & $48(32.2)$ & $9(39.1)$ & $57(33.1)$ & 0.512 \\
\hline Coronary artery disease, $\mathrm{n}(\%)$ & $28(18.7)$ & $7(30.4)$ & $35(20.3)$ & 0.263 \\
\hline Hyperlipidemia, n (\%) & $55(36.9)$ & $9(39.1)$ & $64(37.2)$ & 0.838 \\
\hline COPD, n (\%) & $35(23.4)$ & $8(34.7)$ & $43(25.0)$ & 0.244 \\
\hline Current smoker, n (\%) & $17(11.4)$ & $3(13.0)$ & $20(11.6)$ & 0.737 \\
\hline Heart failure, $\mathrm{n}(\%)$ & $1(0.6)$ & $1(4.3)$ & $2(1.1)$ & 0.250 \\
\hline Body mass index, $\mathrm{kg} / \mathrm{m}^{2}$ & $28.3 \pm 4.9$ & $29.4 \pm 5.2$ & $28.4 \pm 4.9$ & 0.294 \\
\hline Systolic blood pressure, $\mathrm{mmHg}$ & $122.5 \pm 13.0$ & $126.6 \pm 21.0$ & $118.6 \pm 13.6$ & 0.387 \\
\hline Diastolic blood pressure, $\mathrm{mmHg}$ & $70.7 \pm 7.5$ & $74.1 \pm 11.3$ & $71.2 \pm 8.1$ & 0.190 \\
\hline Heart rate, bpm & $82.5 \pm 10.1$ & $86.0 \pm 10.2$ & $82.9 \pm 10.2$ & 0.127 \\
\hline Glucose, mg/dL & $135(108-145)$ & $114(92-259)$ & $133(105-145)$ & 0.866 \\
\hline Hemoglobin, g/dL & $14.3 \pm 1.6$ & $13.2 \pm 1.6$ & $14.1 \pm 1.6$ & 0.004 \\
\hline $\mathrm{WBC}, 10^{3} / \mathrm{uL}$ & $5.5(4.6-7.2)$ & $5.9(5.1-9.7)$ & $5.7(4.7-7.2)$ & 0.171 \\
\hline Platelet count, $10^{3} / \mathrm{uL}$ & $214.0(180.0-254.5)$ & $178.0(158.0-211.0)$ & $209.0(176.0-249.8)$ & 0.003 \\
\hline NLR & $1.8(1.2-2.6)$ & $5.6(2.9-8.1)$ & $1.9(1.3-3.2)$ & $<0.001$ \\
\hline Neutrophil, $10^{3} / \mathrm{uL}$ & $3.2(2.5-4.2)$ & $4.7(3.5-7.7)$ & $3.4(2.6-4.7)$ & $<0.001$ \\
\hline Lymphocyte, $10^{3} / \mathrm{uL}$ & $1.8(1.4-2.4)$ & $0.9(0.7-0.9)$ & $1.7(1.2-2.3)$ & $<0.001$ \\
\hline MPV, fL & $9.0 \pm 0.9$ & $9.0 \pm 0.9$ & $9.0 \pm 0.9$ & 0.950 \\
\hline Urea, mg/dL & $27.5(22.7-34.5)$ & $47.6(32.3-68.7)$ & $29.7(23.3-36.6)$ & $<0.001$ \\
\hline Creatinine, $\mathrm{mg} / \mathrm{dL}$ & $0.78(0.66-0.91)$ & $1.06(0.73-1.41)$ & $0.80(0.67-0.97)$ & $<0.001$ \\
\hline GFR, $\mathrm{ml} / \mathrm{min} / 1.73 \mathrm{~m}^{2}$ & $101.04 \pm 24.1$ & $70.7 \pm 27.7$ & $96.9 \pm 26.6$ & $<0.001$ \\
\hline AST, U/L & $23.0(18.0-30.5)$ & $37.0(29.0-57.0)$ & $23.5(18.3-32.0)$ & $<0.001$ \\
\hline ALT, U/L & $21.0(13.5-31.5)$ & $21.0(14.0-26.0)$ & $21.0(14.0-30.0)$ & 0.850 \\
\hline $\mathrm{LDH}, \mathrm{U} / \mathrm{L}$ & $190.0(151.5-229.0)$ & $353.0(279.0-514.0)$ & $201.0(155.0-254.0)$ & $<0.001$ \\
\hline ALP, U/L & $75.0(62.0-93.5)$ & $67.0(53.5-83.5)$ & $74.0(61.0-92.3)$ & 0.199 \\
\hline $\begin{array}{l}\text { Time from onset of symptom to } \\
\text { hospitalization, day }\end{array}$ & $2(1-6)$ & $4(1-8)$ & $2(1-8)$ & $<0.001$ \\
\hline Length of stay, day & $12(10-14)$ & $14(12-22)$ & $12(10-15)$ & $<0.004$ \\
\hline In-hospital mortality, n (\%) & $5(3.4)$ & $12(52.2)$ & $17(9.9)$ & $<0.001$ \\
\hline
\end{tabular}


Glomerular filtration rate, AST: Aspartate aminotransferase, ALT: Alanine aminotransferase LDH: Lactate dehydrogenase, ALP: Alkaline phosphatase.

Hemoglobin, platelet count, lymphocyte count, GFR were significantly lower in patients treated in the ICU; whereas neutrophil count, NLR, urea, creatinine, AST, and LDH values were significantly higher $(\mathrm{p}<0.05$, for all). The inhospital all-cause mortality rate of patients treated in the ICU was statistically higher than in patients treated in the ward $(\mathrm{p}<0.001)$. When ECG parameters obtained on admission were compared; $\mathrm{PR}$ duration, $\mathrm{P}$-wave dispersion, $\mathrm{QRS}_{\mathrm{d}}, \mathrm{QT}_{\mathrm{c}}$, and $\mathrm{QT}_{\mathrm{d}}$ were significantly longer in patients treated in the ICU ( $\mathrm{p}<0.001$, for all) (Table 2).

Table 2. ECG findings of the study population by the treating unit

\begin{tabular}{lcccc}
\hline & $\begin{array}{c}\text { Inpatient room } \\
(\mathbf{n : ~ 1 4 9 )}\end{array}$ & $\begin{array}{c}\text { ICU } \\
(\mathbf{n : 2 3})\end{array}$ & $\begin{array}{c}\text { Overall } \\
(\mathbf{n : ~ 1 7 2 )}\end{array}$ & $\boldsymbol{p}$-value \\
\hline PR interval, ms & $148.9 \pm 23.8$ & $171.2 \pm 31.2$ & $151.8 \pm 25.9$ & $\mathbf{0 . 0 0 4}$ \\
\hline P-wave dispersion, ms & $56.41 \pm 13.73$ & $71.19 \pm 13.40$ & $58.32 \pm 14.52$ & $<\mathbf{0 . 0 0 1}$ \\
\hline QRS duration, ms & $91.5 \pm 14.7$ & $107.6 \pm 20.5$ & $93.6 \pm 16.4$ & $\mathbf{0 . 0 0 2}$ \\
\hline QTc interval, ms & $415.2 \pm 26.3$ & $446.6 \pm 33.5$ & $419.3 \pm 29.2$ & $<\mathbf{0 . 0 0 1}$ \\
\hline QT dispersion, ms & $51.2 \pm 10.4$ & $65.9 \pm 12.5$ & $53.1 \pm 11.7$ & $<\mathbf{0 . 0 0 1}$ \\
\hline fQRS, n $(\%)$ & $3(2.1)$ & $2(9.5)$ & $5(3.1)$ & 0.126 \\
\hline RBBB, $\mathrm{n}(\%)$ & $11(7.3)$ & $1(4.3)$ & $12(6.9)$ & 1.000 \\
\hline Premature atrial contraction, $\mathrm{n}(\%)$ & $15(10.0)$ & $5(21.7)$ & $20(11.6)$ & 0.153 \\
\hline Premature ventricular contraction, $\mathrm{n}(\%)$ & $24(16.1)$ & $7(30.4)$ & $31(18.0)$ & 0.140 \\
\hline ST-segment depression, $\mathrm{n}(\%)$ & $38(25.5)$ & $9(39.1)$ & $47(27.3)$ & 0.172 \\
\hline ST-segment elevation, $\mathrm{n}(\%)$ & $4(2.6)$ & $1(4.3)$ & $5(2.9)$ & 0.517 \\
\hline T-wave inversion, $\mathrm{n}(\%)$ & $31(20.8)$ & $8(34.7)$ & $39(22.6)$ & 0.136 \\
\hline fQRS: $)$
\end{tabular}

fQRS: fragmente QRS, RBBB: Right bundle branch block.

When we analyzed the predictors of ICU admission (Table 3); in backward stepwise logistic regression analysis, NLR (OR: $1.550,95 \% \mathrm{Cl}$ : 1.037-2.316, $\mathrm{p}=0.032), \mathrm{QT}_{\mathrm{d}}(\mathrm{OR}: 1.093,95 \% \mathrm{Cl}$ : 1.018-1.174, $\mathrm{p}=0.014)$, GFR (OR: 0.959, 95\% Cl: $0.924-0.996, \mathrm{p}=0.030)$, and LDH (OR: $1.013,95 \%$ $\mathrm{Cl}: 1.005-1.022, \mathrm{p}=0.003)$ predicted ICU admission. In ROC analyses for predicting ICU admission; a cut-off value of $>269 \mathrm{U} / \mathrm{L}$ for LDHhad an 82.6 $\%$ sensitivity and $88.4 \%$ specificity[AUC: 0.909 , $95 \%$ CI $0.854-0.948, \mathrm{p}<0.001]$, a cut-off value of $>3.83$ for NLR had a $69.6 \%$ sensitivity and 91.9 $\%$ specificity [AUC: $0.896,95$
$\%$ CI 0.839-0.939, p<0.001], a cut-off value of $>54 \mathrm{~ms}$ for $\mathrm{QT}_{\mathrm{d}}$ had a $90.5 \%$ sensitivity and 65.9 $\%$ specificity [AUC: $0.824,95 \%$ CI $0.757-0.879$, $\mathrm{p}<0.001]$, and a cut-off value of $\leq 82 \mathrm{ml} / \mathrm{min} / 1.73$ $\mathrm{m} 2$ for GFR had a $69.6 \%$ sensitivity and $77.9 \%$ specificity [AUC: $0.806,95 \%$ CI $0.737-0.864$, $\mathrm{p}<0.001]$ (Fig 1). In the pairwise comparison of ROC curves; There was no significant difference ( $>>0.05$, for all) (supplementary appendix).

The demographic characteristics, laboratory data, and ECG findings of the patients with and without in-hospital mortality are shown in Table 4.

Table 3. Independent risk factors of ICU admission

\begin{tabular}{|c|c|c|c|c|}
\hline \multirow[t]{2}{*}{ Variable } & \multicolumn{2}{|c|}{ Univariate Analysis } & \multicolumn{2}{|c|}{ Multivariate Analysis } \\
\hline & OR (95 \% CI) & $p$-value & OR (95 \% CI) & $p$-value \\
\hline Age, years & $1.090(1.052-1.130)$ & $<0.001$ & - & - \\
\hline Gender, male & $1.428(0.590-3.460)$ & 0.430 & - & - \\
\hline NLR & $2.120(1.567-2.869)$ & $<0.001$ & $1.550(1.037-2.316)$ & 0.032 \\
\hline PR interval, ms & $1.030(1.013-1.048)$ & 0.001 & - & - \\
\hline $\mathrm{P}$-wave dispersion, $\mathrm{ms}$ & $1.069(1.034-1.105)$ & $<0.001$ & - & - \\
\hline QRS duration, ms & $1.054(1.025-1.083)$ & $<0.001$ & - & - \\
\hline $\mathrm{QT}_{\mathrm{c}}$ interval, ms & $1.041(1.021-1.061)$ & $<0.001$ & - & - \\
\hline QT dispersion, ms & $1.103(1.058-1.150)$ & $<0.001$ & $1.093(1.018-1.174)$ & 0.014 \\
\hline $\mathrm{GFR}, \mathrm{ml} / \mathrm{min} / 1.73 \mathrm{~m}^{2}$ & $0.948(0.927-0.970)$ & $<0.001$ & $0.959(0.924-0.996)$ & 0.030 \\
\hline Hemoglobin, g/dL & $0.664(0.497-0.887)$ & 0.006 & - & - \\
\hline Platelet count, $x 10^{3} / \mu \mathrm{L}$ & $0.993(0.985-1.002)$ & 0.133 & - & - \\
\hline LDH, U/L & $1.019(1.011-1.026)$ & $<0.001$ & $1.013(1.005-1.022)$ & 0.003 \\
\hline $\mathrm{AST}, \mathrm{U} / \mathrm{L}$ & $1.056(1.028-1.085)$ & $<0.001$ & - & - \\
\hline
\end{tabular}

$p$-value < 0.05 was considered significant. Nagelkerke $\mathrm{R}^{2}: 0.739, \mathrm{p}<0.001$. NLR: Neutrophil to lymphocyte ratio, GFR: Glomerular filtration rate, AST: Aspartate aminotransferase, LDH: Lactate dehydrogenase. 


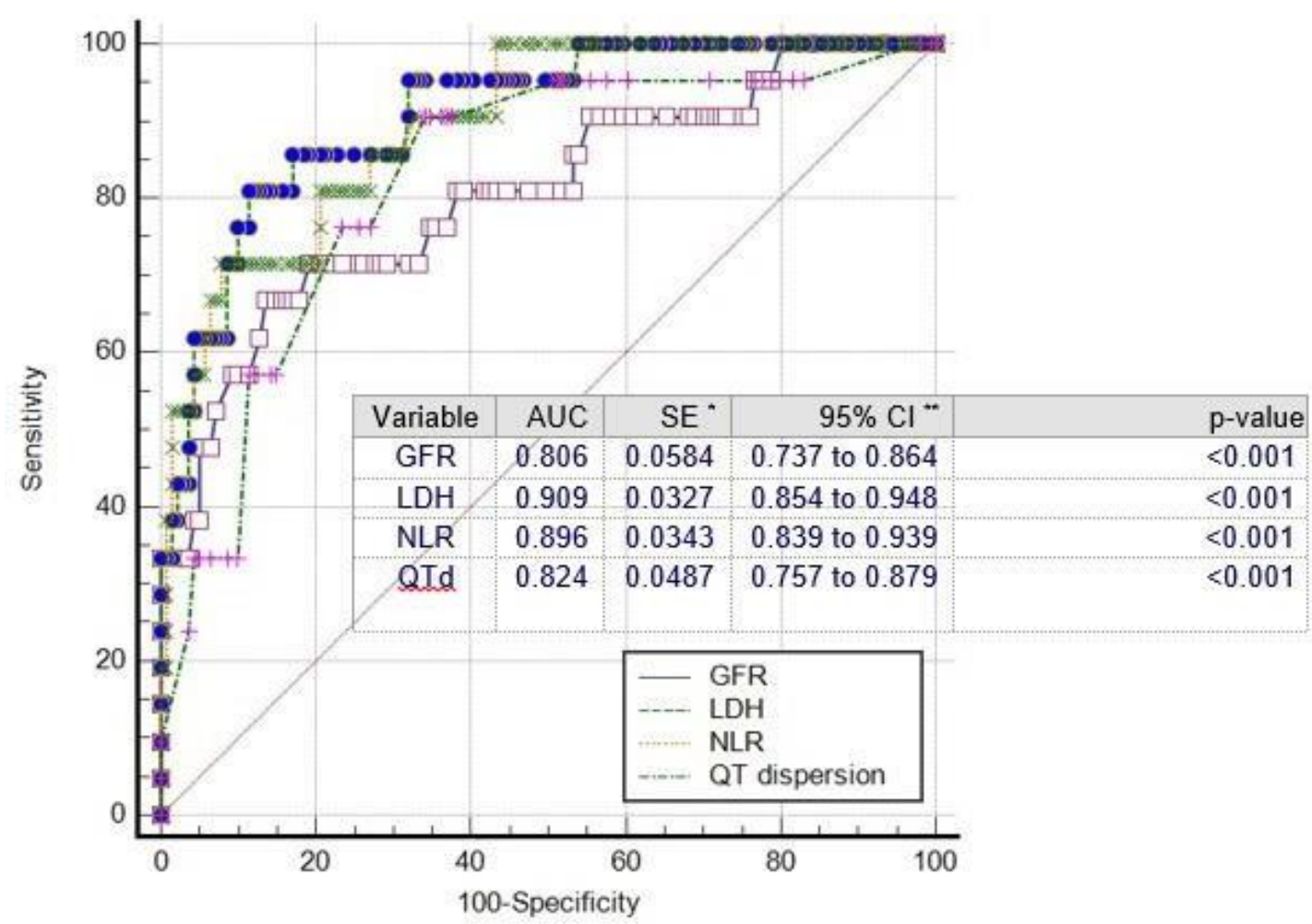

Figure 1. Receiver operating characteristic (ROC) curves of predictors for ICU admission in patients with COVID-19. SE: standart error. CI: confidence interval.

Table 4. Demographic and laboratory findings of the study population by in-hospital mortality status

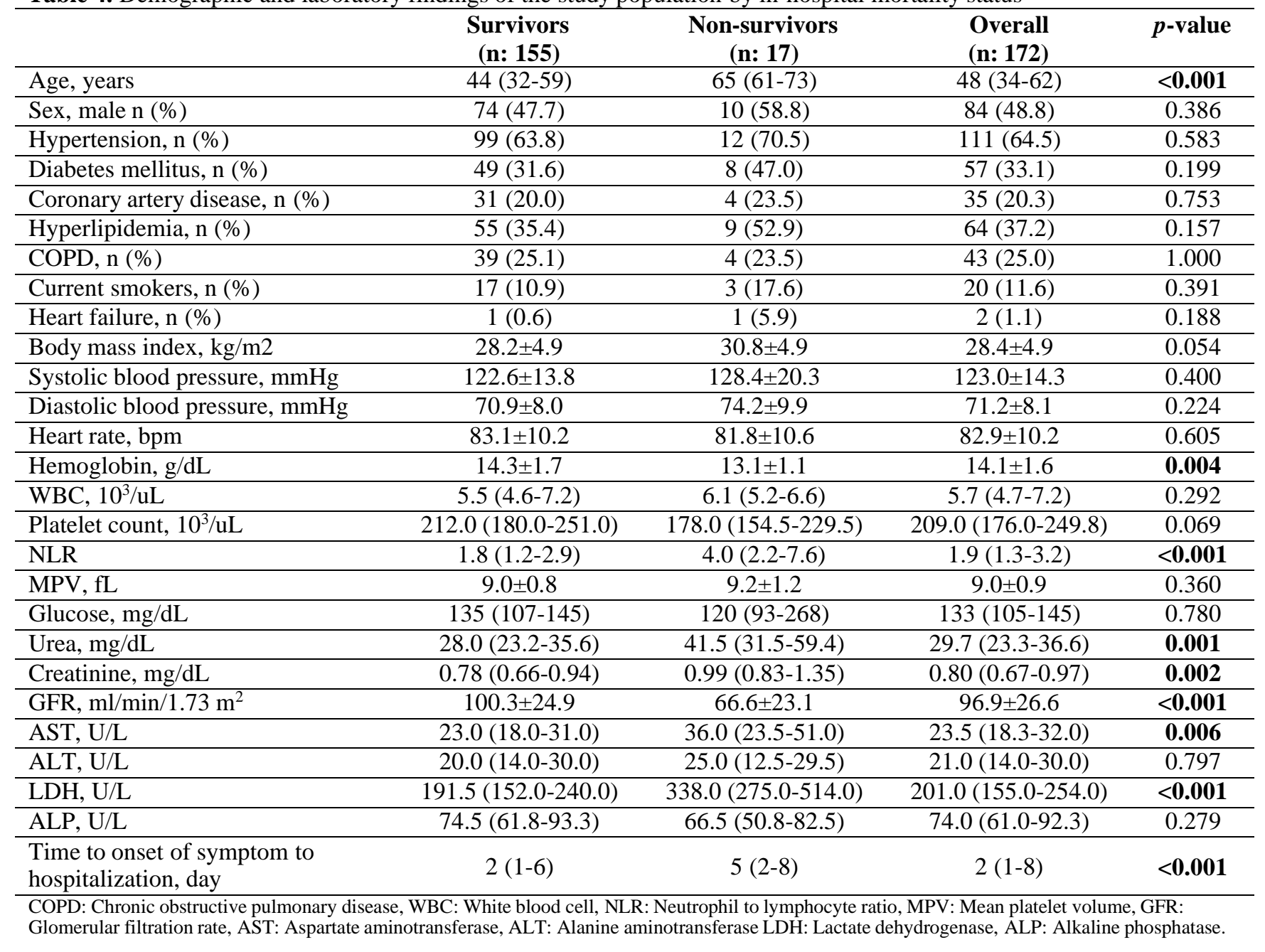


There was no significant difference in gender and comorbid diseases between survivors and non-survivors. The median age was significantly higher in the non-survivor group [65 (61-73) vs. 44 (32-59); $\mathrm{p}<0.001]$. Hemoglobin and GFR were lower in the non-survivor group, whereas NLR, glucose, AST, urea, creatinine, time to onset of symptom to hospitalization, and $\mathrm{LDH}$ were significantly higher $(\mathrm{p}<0.05$, for all). PR duration, $\mathrm{P}$-wave dispersion, $\mathrm{QRS}_{\mathrm{d}}, \mathrm{QT}_{\mathrm{d}}$, and $\mathrm{QT}_{\mathrm{c}}$ were significantly longer in the non-survivor group compared with survivors $(\mathrm{p}<0.05$, for all) (Table 5$)$.

Table 5. ECG findings of the patients by in-hospital mortality status

\begin{tabular}{lcccc}
\hline & $\begin{array}{c}\text { Survivors } \\
(\mathbf{n}: \mathbf{1 5 5})\end{array}$ & $\begin{array}{c}\text { Non-survivors } \\
(\mathbf{n : 1 7 )}\end{array}$ & $\begin{array}{c}\text { Overall } \\
(\mathbf{n : 1 7 2})\end{array}$ & $\boldsymbol{p}$-value \\
\hline PR interval, ms & $149.9 \pm 24.6$ & $179.7 \pm 29.6$ & $151.8 \pm 25.9$ & $<\mathbf{0 . 0 0 1}$ \\
\hline P-wave dispersion, ms & $57.3 \pm 14.1$ & $74.0 \pm 12.6$ & $58.3 \pm 14.5$ & $<\mathbf{0 . 0 0 1}$ \\
\hline QRS duration, ms & $92.3 \pm 15.0$ & $113.5 \pm 23.3$ & $93.6 \pm 16.4$ & $\mathbf{0 . 0 1 8}$ \\
\hline QTc interval, ms & $417.8 \pm 28.4$ & $441.1 \pm 34.1$ & $419.3 \pm 29.2$ & $\mathbf{0 . 0 1 4}$ \\
\hline QT dispersion, ms & $52.4 \pm 11.5$ & $64.0 \pm 11.0$ & $53.1 \pm 11.7$ & $\mathbf{0 . 0 0 2}$ \\
\hline fQRS, $\mathrm{n}(\%)$ & $4(2.6)$ & $1(5.8)$ & $5(3.1)$ & 0.276 \\
\hline RBBB, $\mathrm{n}(\%)$ & $10(6.5)$ & $2(11.7)$ & $12(6.9)$ & 0.337 \\
\hline Premature atrial contraction, $\mathrm{n}(\%)$ & $16(10.3)$ & $4(23.5)$ & $20(11.6)$ & 0.116 \\
\hline remature ventricular contraction, $\mathrm{n}(\%)$ & $28(18.0)$ & $3(17.6)$ & $31(18.0)$ & 1.000 \\
\hline ST-segment depression, $\mathrm{n}(\%)$ & $42(27.0)$ & $5(29.4)$ & $47(27.3)$ & 0.782 \\
\hline ST-segment elevation, $\mathrm{n}(\%)$ & $4(2.6)$ & $1(5.8)$ & $5(2.9)$ & 0.410 \\
\hline T-wave inversion, $\mathrm{n}(\%)$ & $33(21.2)$ & $6(35.2)$ & $39(22.6)$ & 0.223 \\
\hline fQRS: fragmente QRS, RBBB: Right bundle branch block. & & &
\end{tabular}

There was no difference in terms of fragmented QRS between the groups. In multivariate regression analysis with backward selection, $\mathrm{QRS}_{\mathrm{d}}$ (OR: 1.045, 95\% Cl: 1.000-1.091, $\mathrm{p}=0.049)$, GFR (OR: 0.922, 95\% Cl: 0.875-0.972, $\mathrm{p}=0.003)$ and LDH (OR: 1.009, 95\% Cl: 1.003 $1.015, \mathrm{p}=0.003)$ predicted in-hospital all-cause mortality (Table 6).

Table 6. Independent risk factors of all-cause in-hospital mortality of patients with COVID-19

\begin{tabular}{|c|c|c|c|c|}
\hline \multirow[t]{2}{*}{ Variable } & \multicolumn{2}{|c|}{ Univariate Analysis } & \multicolumn{2}{|c|}{ Multivariate Analysis } \\
\hline & OR $(95 \%$ CI $)$ & $p$-value & OR $(95 \% \mathrm{CI})$ & $p$-value \\
\hline Age, years & $1.074(1.037-1.113)$ & $<0.001$ & - & - \\
\hline Gender, male & $1.564(0.566-4.319)$ & 0.388 & - & - \\
\hline Body mass index, $\mathrm{kg} / \mathrm{m}^{2}$ & $1.101(0.996-1.217)$ & 0.059 & - & - \\
\hline QRS duration, $\mathrm{ms}$ & $1.061(1.026-1.098)$ & 0.001 & $1.045(1.000-1.091)$ & 0.049 \\
\hline $\mathrm{QT}_{\mathrm{c}}$ interval, ms & $1.026(1.004-1.049)$ & 0.019 & - & - \\
\hline QT dispersion, ms & $1.072(1.021-1.125)$ & 0.005 & - & - \\
\hline PR interval, $\mathrm{ms}$ & $1.037(1.014-1.061)$ & 0.001 & - & - \\
\hline $\mathrm{P}$-wave dispersion, $\mathrm{ms}$ & $1.074(1.027-1.123)$ & 0.002 & - & - \\
\hline NLR & $1.221(1.064-1.401)$ & 0.004 & - & - \\
\hline Hemoglobin, g/dL & $0.626(0.450-0.871)$ & 0.005 & - & - \\
\hline $\mathrm{GFR}, \mathrm{ml} / \mathrm{min} / 1.73 \mathrm{~m}^{2}$ & $0.942(0.918-0.968)$ & $<0.001$ & $0.922(0.875-0.972)$ & 0.003 \\
\hline AST, U/L & $1.045(1.018-1.073)$ & 0.001 & - & - \\
\hline $\mathrm{LDH}, \mathrm{U} / \mathrm{L}$ & $1.009(1.004-1.013)$ & $<0.001$ & $1.009(1.003-1.015)$ & 0.003 \\
\hline
\end{tabular}

$p$-value $<0.05$ was considered significant. Nagelkerke $\mathrm{R}^{2}: 0.662, \mathrm{p}<0.001$. NLR: Neutrophil to lymphocyte ratio, GFR: Glomerular filtration rate, AST: Aspartate aminotransferase, LDH: Lactate dehydrogenase.

\section{DISCUSSION}

Few reports have been published regarding the relationship between ECG findings and ICU admission and all-cause in-hospital mortality in infectious diseases, especially in COVID-19 patients. Consequently, convincing evidence has been yet to found. In the present study, according to ECGs obtained during admission to the hospital; we found an independent association between ICU admission and $\mathrm{QT}_{\mathrm{d}}$, and between $\mathrm{QRS}_{\mathrm{d}}$ and inhospital all-cause mortality.
The increased risk of myocardial involvement in COVID-19 patients explains the conduction disturbance and thus the change in $\mathrm{QRS}_{\mathrm{d}}$. Although this was not the aim of our study, the increased in-hospital mortality and postdischarge sudden cardiac death in COVID-19 patients with myocardial involvement may be partially attributable to the prolonged $\mathrm{QRS}_{\mathrm{d}}(22)$. In our study, the relationship between $\mathrm{QRS}_{\mathrm{d}}$ and inhospital all-cause mortality, and prolonged $\mathrm{QRS}_{\mathrm{d}}$ in the ICU admission group seem to support this theory. In addition, comparing COVID-19 and 
other acute respiratory infectious diseases, Antonio et al. revealed that increased $\mathrm{QRS}_{\mathrm{d}}$ is associated with mortality. Similarly, another investigation of 324 COVID-19 patients compared the ECG findings and reported that an increase in $\mathrm{QRS}_{\mathrm{d}}$ predicted mortality (23). The mechanisms underlying the association between prolonged $\mathrm{QRS}_{\mathrm{d}}$ and mortality may also be explained by left ventricular dysfunction, repolarization abnormalities, and malignant arrhythmias.

Increasing dispersion of repolarization that indicates heterogeneity of repolarization is a marker of crucial ventricular arrhythmias (24-27). $\mathrm{QT}_{\mathrm{d}}$ contributes to the heterogeneities of repolarization time in the three-dimensional structure of the ventricular myocardium, which is secondary to regional differences in action potential duration and activation time $(28,29)$. The association of $\mathrm{QT}_{\mathrm{d}}$ with cardiac arrhythmia is thought to be related to the sympathetic innervation of the left ventricle (30). Increased sympathetic innervation in COVID19 patients also strengthens this relationship (31). Even though the relationship between $\mathrm{QT}_{d}$ and arrhythmias is relatively clear, there are conflicting results regarding its relationship with mortality. For instance, in a meta-analysis (32); prolonged $\mathrm{QT}_{\mathrm{d}}$ in myocardial infarction has been reported to be associated with an increase in arrhythmic events, but not with all-cause mortality. These conflicting results may be attributed to the various reasons stated as follows: (i) $\mathrm{QT}_{\mathrm{d}}$ may rather describe $\mathrm{T}$ wave morphology than ventricular repolarization (33), (ii) The reproducibility of $\mathrm{QT}_{\mathrm{d}}$ measurement is low and inter-observer error might be $>20 \%$ (33), (iii) Difficulty in identifying $\mathrm{T}$ wave-end when measuring the QT interval, and differences of opinion about whether it is calculated according to heart rate could indicate the subjectivity of $\mathrm{QT}_{\mathrm{d}}$. In the present study, we found that $\mathrm{QT}_{\mathrm{d}}$ predicted ICU admission but not in-hospital all-cause mortality. This discordance may be associated with several plausible reasons such as the selection of inhospital all-cause mortality over cardiovascular mortality as an endpoint, insufficient number of in- hospital mortality for the model fit of statistical analysis.

In our results, GFR, LDH, and NLR were associated with poor outcomes, compatible with the literature. However, those with co-morbidities such as coronary artery disease or chronic obstructive pulmonary disease did not seem to have a worse prognosis during hospitalization. This could be attributed to the inclusion of only hospitalized patients with COVID-19 and the criteria for hospitalization. Therefore, this methodological approach may be causing an equal distribution of comorbidities across the groups.

Limitations

The present study has the following notable limitations. The main limitations are the sample size of the population and study design without long-term follow-up. Since only the ECGs on admission were evaluated, we did not examine ECG changes during hospitalization and their relationship with in-hospital all-cause mortality. The results cannot be generalized to other segments of the population, as the study was conducted at a single center. Another substantial limitation is that the low number of patients in the non-survivors group may affect the reliability of statistical analysis on in-hospital mortality. Finally, since the criteria for admission to ICU are determined according to the interim guidance of the Turkish Ministry of Health, alterations in these criteria may give rise to changes in the results of the study. Further comprehensive prospective investigations with long-term follow-up and a large sample size are needed to better clarify the association of findings on ECG with morbidity and mortality in COVID-19 patients.

\section{CONCLUSION}

We found that ECG findings on admission were independently associated with in-hospital allcause mortality and ICU admission in patients with COVID-19. Consequently, these results suggest that ECGs on admission might enable clinicians to determine the treatment priority of patients as well as to predict prognosis.

\section{Conflicts of interest: No}

\section{REFERENCES}

1. Garg S, Kim L, Whitaker M, O'Halloran A, Cummings C, Holstein R, et al. Hospitalization Rates and Characteristics of Patients Hospitalized with Laboratory-Confirmed Coronavirus Disease 2019 - COVIDNET, 14 States, March 1-30, 2020. MMWR Morb Mortal Wkly Rep 2020;69:458-64.

2. Huang C, Wang Y, Li X, Ren L, Zhao J, Hu Y, et al. Clinical features of patients infected with 2019 novel coronavirus in Wuhan, China. Lancet 2020;395:497-506. https://doi.org/10.1016/S0140-6736 (20)30183-5.

3. Eaaswarkhanth M, Al Madhoun A, Al-Mulla F. Could the D614G substitution in the SARS-CoV-2 spike(S) protein be associated with higher COVID-19 mortality? Int J Infect Dis 2020;96:459-60. https://doi.org/10.1016/j.ijid.2020.05.071.

4. Lai CC, Liu YH, Wang CY, Wang YH, Hsueh SC, Yen MY, et al. Asymptomatic carrier state, acute respiratory disease, and pneumonia due to severe acute respiratory syndrome coronavirus 2 (SARS-CoV2): Facts and myths. J Microbiol Immunol Infect 2020;53:404-12. https://doi.org/10.1016/j.jmii.2020.02.012

5. Bai Y, Yao L, Wei T, Tian F, Jin DY, Chen L, et al. Presumed Asymptomatic Carrier Transmission of COVID-19. JAMA2020;323:1406-7 https://doi.org/10.1001/jama.2020.2565. 
6. Xu H, Zhong L, Deng J, Peng J, Dan H, Zeng X, et al. High expression of ACE2 receptor of 2019-nCoV on the epithelial cells of oral mucosa.Int J Oral Sci 2020;12:8. doi: 10.1038/s41368-020-0074-X.

7. Zhou R. Does SARS-CoV-2 cause viral myocarditis in COVID-19 patients? Eur Heart J 2020;41:2123. doi: 10.1093/eurheartj/ehaa392.

8. IC Kim, JY Kim, HA Kim, S Han. COVID-19-related myocarditis in a 21-year-old female patient. Eur Heart J 2020;41:1859. doi: 10.1093/eurheartj/ehaa288.

9. Inciardi RM, Adamo M, Lupi L, Cani DS, Di Pasquale M, Tomasoni D, et al. Characteristics and outcomes of patients hospitalized for COVID-19 and cardiac disease in Northern Italy. Eur Heart J 2020;41:1821-29. doi: 10.1093/eurheartj/ehaa388.

10. Argenziano MG, Bruce SL, Slater CL, Tiao JR, Baldwin MR, Barr RG, et al. Characterization and clinical course of 1000 Patients with COVID-19 in New York: retrospective case series. medRxiv 2020;2020.04.20.20072116. doi: 10.1101/2020.04.20.20072116.

11. Lanza GA, De Vita A, Ravenna SE, D’Aiello A, Covino M, Franceschi F,et al. Electrocardiographic findings at presentation and clinical outcome in patients with SARS-CoV-2 infection. Europace 2020; euaa245. doi: 10.1093/europace/euaa245.

12. Rautaharju PM, Ge S, Nelson JC, Marino Larsen EK, Psaty BM, Furberg CD, et al. Comparison of mortality risk for electrocardiographic abnormalities in men and women with and without coronary heart disease (from the Cardiovascular Health Study). Am J Cardiol. 2006;97:309-15. doi: 10.1016/j.amjcard.2005.08.046.

13. Lund LH, Jurga J, Edner M, Benson L, Dahlström U, Linde C, et al. Prevalence, correlates, and prognostic significance of QRS prolongation in heart failure with reduced and preserved ejection fraction. Eur Heart $\mathbf{J}$ 2013;34:529-39. doi: 10.1093/eurheartj/ehs305.

14. Ogiso M, Suzuki A, Shiga T, Nakai K, Shoda M, Hagiwara N. Effect of intravenous amiodarone on QT and $\mathrm{T}$ peak-T end dispersions in patients with nonischemic heart failure treated with cardiac resynchronizationdefibrillator therapy and electrical storm. J Arrhythm 2015;31:1-5. doi: 10.1016/j.joa.2014.01.006.

15. Glancy JM, Garratt CJ, Woods KL, de Bono DP. QT dispersion and mortality after myocardial infarction. Lancet 1995;345:945-8. doi:10.1016/ S0140-6736(95)90697-5.

16. Buja G, Miorelli M, Turrini P, Melacini P, Nava A. Comparison of QT dispersion in hypertrophic cardiomyopathy between patients with and without ventricular arrhythmias and sudden death. Am J Cardiol 1993;72:973-6. doi:10.1016/0002-9149(93)91118-2.

17. Prigent A. Monitoring renal function and limitations of renal function tests. Semin Nucl Med 2008;38:3246. doi: 10.1053/j.semnuclmed.2007.09.003.

18. Ministry of Health. COVID-19 algoritmalar [online]; 2020 Website: https:// covid19bilgi.saglik.gov.tr/tr/algoritmalar [accessed 17April 2020].

19. Bazett HC. The time relations of the blood-pressure changes after excision of the adrenal glands, with some observations on blood volume changes. J Physiol 1920;53:320-39. doi: 10.1113/jphysiol.1920.sp001881.

20. Priori SG, Napolitano C, Diehl L, Schwartz PJ. Dispersion of the QT interval. A marker of therapeutic efficacy in the idiopathic long QT syndrome. Circulation 1994;89:1681-9. doi: 10.1161/01.cir.89.4.1681.

21. Dilaveris PE, Gialafos EJ, Sideris SK, Theopistou AM, Andrikopoulos GK, Kyriakidis M, et al.Simple electrocardiographic markers for the prediction of paroxysmal idiopathic atrial fibrillation. Am Heart J. 1998;135:733-8. doi: 10.1016/s0002-8703(98)70030-4.

22. Goldberger JJ, Cain ME, Hohnloser SH, Kadish AH, Knight BP, Lauer MS, et al. American Heart Association/american College of Cardiology Foundation/heart Rhythm Society scientific statement on noninvasive risk stratification techniques for identifying patients at risk for sudden cardiac death: a scientific statement from the American Heart Association Council on Clinical Cardiology Committee on Electrocardiography and Arrhythmias and Council on Epidemiology and Prevention. Circulation 2008;118:1497-518.

23. Lanza GA, De Vita A, Ravenna SE, D'Aiello A, Covino M, Franceschi F, et al.Electrocardiographic findings at presentation and clinical outcome in patients with SARS-CoV-2 infection. Europace 2020; euaa245. doi: 10.1093/europace/euaa245.

24. Han J, Goel BG. Electrophysiologic precursors of ventricular tachyarrhythmias. Arch Intern Med. 1972;129:749-55.

25. Mirvis DM. Spatial variation of QT intervals in normal persons and patients with acute myocardial infarction. J Am Coll Cardiol 1985;5:625-31. doi: 10.1016/s0735-1097(85)80387-9.

26. Puljevic D, Smalcelj A, Durakovic Z, Goldner V. QT dispersion, daily variations, QT interval adaptation and late potentials as risk mark- ers for ventricular tachycardia. Eur Heart J 1997;18:1343-9. doi: 10.1093/oxfordjournals.eurheartj.a015448.

27. Barr CS, Naas A, Freeman M, Lang CC, Struthers AD. QT dispersion and sudden unexpected death in chronic heart failure. Lancet 1994;343:327-9. doi: 10.1016/s0140-6736(94)91164-9.

28. Antzelevitch C, Shimizu W, Yan GX, Sicouri S. Cellular basis for QT dispersion. J Electrocardiol 1998;30 Suppl:168-75. doi: 10.1016/s0022-0736(98)80070-8. 
29. Bogun F, Chan KK, Harvey M, Goyal R, Castellani M, Niebauer M, et al. QT dispersion in nonsustained ventricular tachycardia and coronary artery disease. Am J Cardiol 1996;77:256-9. doi: 10.1016/s00029149(97)89389-7.

30. Minisi AJ, Thames MD. Distribution of left ventricular sympathetic afferents demonstrated by reflex responses to transmural myocardial ischemia and to intracoronary and epicardial bradykinin. Circulation 1993;87:240-6. doi: 10.1161/01.cir.87.1.240.

31. Porzionato A, Emmi A, Barbon S, Boscolo-Berto R, Stecco C, Stocco E, et al. Sympathetic activation: a potential link between comorbidities and COVID-19. The FEBS journal 2020;287:3681-8. https://doi.org/10.1111/febs.15481.

32. Bazoukis G, Yeung C, Wui Hang Ho R, Varrias D, Papadatos S, Lee S, et al.Association of QT dispersion with mortality and arrhythmic events-A meta-analysis of observational studies. J Arrhythm 2019;36:10515. doi: 10.1002/joa3.12253.

33. Kors JA, van Herpen G, van Bemmel JH. QT dispersion as an attribute of T-loop morphology. Circulation 1999;99:1458-63. doi: 10.1161/01.cir.99.11.1458. 